Jurnal Penelitian dan Pengabdian Kepada Masyarakat Bidang ilmu Pendidikan

\title{
Upaya Meningkatkan Aktivitas dan Hasil Belajar Fisika Melalui Pembelajaran Kooperatif Tipe Think Pair Share (TPS) pada siswa kelas XI IPA 3 SMA Negeri 1 Woja Tahun Pembelajaran 2018/2019
}

\author{
Ernawati Rahmaniah \\ SMA Negeri 1 Woja, Kabupaten Dompu, Nusa Tenggara Barat \\ E-mail: ernawati. rahmaniah.dompu@gmail.com
}

Article History: Received: 2020-10-09 || Revised: 2020-11-03 || Published: 2020-12-26

Sejarah Artikel : Diterima: 2020-10-09 || Direvisi: 2020-11-03 || Dipublikasi: 2020-12-26

\begin{abstract}
The objectives of this study are: 1) To increase student learning activities in the physics learning process by applying the Think-Pair-Share (TPS) type of cooperative learning. 2) Improve student learning outcomes in physics subjects by applying the Think-Pair-Share (TPS) type of cooperative learning. This research was conducted on Class XI IPA 3 students of SMA Negeri 1 Woja in the odd semester of the 2018/2019 academic year with 30 students. Actions are carried out in 2 cycles with subject matter covering cycle I about 7.4 Mastering the effect of heat on substances and in cycle II about 8.1 Mastering the law of static fluids. The research result data is in the form of student learning activities that are collected using the observation method using the observation format and the student learning outcomes are collected using the learning outcome test. The results of the study based on data analysis showed an increase in activity from an average score of 1.80 with a less active category in the first cycle to a fairly active category in the second cycle with an average score of 2.01. The learning outcomes increased from before the study with an average of 62.00 to 66.93 in the first cycle and 73.25 in the second cycle with completeness achieved by $65.67 \%$ before the study to $77 \%$ in the first cycle and $87 \%$ in the second cycle. complete classification is not finished yet becomes complete. The results of this study indicate that the application of the Think-Pair-Share (TPS) type of cooperative learning model can be used to improve student learning outcomes.
\end{abstract}

Keywords: Learning, Cooperative, Think, Pair, Share, Physics

\begin{abstract}
Abstrak
Tujuan penelitian ini adalah: 1) Meningkatkan Aktivitas belajar siswa dalam proses pembelajaran fisika dengan menerapkan pembelajaran kooperatif tipe Think-Pair-Share (TPS). 2) Meningkatkan hasil belajar siswa pada mata pelajaran fisika dengan menerapkan pembelajaran kooperatif tipe Think-Pair-Share (TPS). Penelitian ini dilakukan pada Siswa Kelas XI IPA 3 SMA Negeri 1 Woja Semester Ganjil Tahun Pelajaran 2018/2019 dengan jumlah siswa 30 orang. Tindakan dilakukan dalam 2 siklus dengan materi pelajaran meliputi pada siklus I tentang 7.4 Menguasai pengaruh kalor terhadap zat dan pada siklus II tentang 8.1 Menguasai hukum fluida statis. Data hasil penelitian berupa Aktivitas belajar siswa yang dikumpulkan dengan metode observasi yang menggunakan format observasi dan hasil belajar siswa dikumpulkan dengan menggunakan tes hasil belajar. Hasil penelitian berdasarkan analisis data menunjukkan adanya peningkatan aktivitas dari skor rata-rata 1,80 dengan katagori kurang aktif pada siklus I menjadi katagori cukup aktif pada siklus II dengan skor rata-rata 2,01. Untuk hasil belajar mengalami peningkatan dari sebelum penelitian dengan rata- rata 62,00 menjadi 66,93 pada siklus I dan 73,25 pada siklus II dengan ketuntasan yang dicapai $65.67 \%$ sebelum penelitian menjadi $77 \%$ pada siklus I dan $87 \%$ pada siklus II dari klasifikasi tuntas belum tuntas menjadi tuntas. Hasil penelitian ini menunjukkkan bahwa penerapan model Pembelajaran Kooperatif tipe Think-Pair-Share (TPS) dapat digunakan untuk meningkatkan hasil belajar siswa
\end{abstract}

Kata kunci: Pembelajaran, Kooperatif, Think, Pair, Share, Fisika

\section{PENDAHULUAN}

Fisika merupakan salah satu cabang IPA yang mendasari perkembangan teknologi maju dan konsep hidup harmonis dengan alam. Perkembangan pesat di bidang teknologi informasi dan komunikasi dewasa ini dipicu oleh temuan di bidang fisika material melalui penemuan piranti mikroelektronika yang mampu memuat banyak informasi dengan ukuran sangat kecil. Sebagai ilmu 
yang mempelajari fenomena alam, fisika juga memberikan pelajaran yang baik kepada manusia untuk hidup selaras berdasarkan hukum alam. Pengelolaan sumber daya alam dan lingkungan serta pengurangan dampak bencana alam tidak akan berjalan secara optimal tanpa pemahaman yang baik tentang fisika.

Pada tingkat SMA, fisika dipandang penting untuk diajarkan sebagai mata pelajaran tersendiri dengan beberapa pertimbangan. Pertama, selain memberikan bekal ilmu kepada peserta didik, mata pelajaran Fisika dimaksudkan sebagai wahana untuk menumbuhkan kemampuan berpikir yang berguna untuk memecahkan masalah di dalam kehidupan sehari-hari. Kedua, mata pelajaran Fisika perlu diajarkan untuk tujuan yang lebih khusus yaitu membekali peserta didik pengetahuan, pemahaman dan sejumlah kemampuan yang dipersyaratkan untuk memasuki jenjang pendidikan yang lebih tinggi serta mengembangkan ilmu dan teknologi. Pembelajaran Fisika dilaksanakan secara inkuiri ilmiah untuk menumbuhkan kemampuan berpikir, bekerja dan bersikap ilmiah serta berkomunikasi sebagai salah satu aspek penting kecakapan hidup.

Mata pelajaran Fisika bertujuan agar peserta didik memiliki kemampuan membentuk sikap positif terhadap fisika dengan menyadari keteraturan dan keindahan alam serta mengagungkan kebesaran Tuhan Yang Maha Esa, memupuk sikap ilmiah yaitu jujur, obyektif, terbuka, ulet, kritis dan dapat bekerjasama dengan orang lain, mengembangkan pengalaman untuk dapat merumuskan masalah, mengajukan dan menguji hipotesis melalui percobaan, merancang dan merakit instrumen percobaan, mengumpulkan, mengolah, dan menafsirkan data, serta mengkomunikasikan hasil percobaan secara lisan dan tertulis, mengembangkan kemampuan bernalar dalam berpikir analisis induktif dan deduktif dengan menggunakan konsep dan prinsip fisika untuk menjelaskan berbagai peristiwa alam dan menyelesaian masalah baik secara kualitatif maupun kuantitatif, serta menguasai konsep dan prinsip fisika serta mempunyai keterampilan mengembangkan pengetahuan, dan sikap percaya diri sebagai bekal untuk melanjutkan pendidikan pada jenjang yang lebih tinggi serta mengembangkan ilmu pengetahuan dan teknologi Hal tersebut mengajak kita selaku guru pada setiap satuan pendidikan untuk berupaya memberikan yang terbaik kepada siswa agar dapat menguasai disetiap kompetensi .Penguasaan tersebut dicerminkan pada hasil belajar

Dari pengalaman dan refleksi dalam pengelolaan pembelajaran fisika di awal semester ganjil di kelas XI IPA 3 di SMA Negeri 1 Woja tahun pelajaran 2018/2019 ditemui bahwa aktivitas siswa dalam mengikuti proses pembelajaran fisika kurang aktif, hal tersebut dibuktikan dengan rendahnya kontribusi siswa saat proses pembelajaran berlangsung. dan peran serta siswa masih didominasi oleh siswa yang memiliki kemampuan lebih. Sementara itu siswa yang kurang mampu tidak memberikan aktivitas disetiap menyelesaikan masalah yang diberikan. Disamping itu juga hasil belajar siswa di kelas tersebut menunjukkan hasil yang tidak memuaskan dibuktikan dengan nilai yang diperoleh siswa rata-rata masih relatif rendah. Jika hal tersebut dibiarkan tentu siswa yang tidak mampu akan terbelakang yang akhirnya akan berdampak pada makna belajar dan ketercapaian hasil belajar siswa tidak maksimal.

Dari kenyataan tersebut diatas perlu adanya alternatif penyelesaian yang memungkinkan sehingga mata pelajaran fisika lebih menyenangkan dan terbantu sehingga akan tumbuh rasa nyaman belajar siswa. Alternatif model pembelajaran yang digunakan yaitu pembelajaran kooperatif tipe Think Pair Share (TPS) yang dikembangkan oleh Kagan dalam (Lie, A, 2002) mengajarkan siswa untuk lebih mandiri dalam mengerjakan soal-soal yang diberikan sehingga dapat membangkitkan rasa percaya diri siswa dimana siswa dapat bekerjasama dengan orang lain dalamkelompok kecil yang heterogen. Melalui model pembelajaran ini diharapkan dapat menyelesaikan masalah tersebut sehinga pembelajaran lebih bermakna dan menyenangkan, dan siswa yang kurang mampu terbantu dalam kelompoknya untuk ikut berpikir, berdiskusi dan saling tukar pikiran dengan siswa yang mampu sehingga dalam menyelesaikan setiap masalah dapat 
teratasi dan menjadikan suasana pembelajaran lebih aktif.

Tujuan penelitian ini adalah (1) Untuk mengetahui peningkatan aktivitas belajar siswa kelas XI IPA 3 SMA Negeri 1 Woja Tahun Pelajaran 2018/2019 dengan penerapan Pembelajaran Kooperatif tipe Think Pair Share (TPS) dan (2) Untuk mengetahui peningkatan ketuntasan hasil belajar siswa kelas XI IPA 3 SMA Negeri 1 Woja Tahun Pelajaran 2018/2019 dengan Penerapan Pembelajaran Kooperatif tipe Think Pair Share ( TPS ).

\section{METODE PENELITIAN}

Penelitian dilakukan pada semester ganjil tahun pelajaran 2018/2019 yang berlokasi di SMA Negeri 1 Woja yang di Kelurahan Kandai Dua, Kecamatan Woja, Kabupaten Dompu. Penelitian ini dilakukan untuk memperbaiki aktivitas dan hasil belajar berdasarkan hasil yang diperoleh dari proses pembelajaan sebelumnya. Subjek penelitian ini adalah siswa kelas XI IPA 3 SMA Negeri 1 Woja dengan jumlah siswa sebanyak 30 orang yang terdiri dari 27 siswa laki-laki dan 3 siswa perempuan, Penelitian tindakan kelas ini dilaksanakan dalam tiga (3) siklus. Setiap siklus terdiri dari empat tahapan yaitu : (1) Perencanaan tindakan, (2) pelaksanaan tindakan, (3) observasi dan evaluasi tindakan dan (4) refleksi siklus.

Teknik dan alat pengumpulan data dalam penelitian ini mengacu pada tujuan penelitian tindakan dengan metode pengumpulan data yang digunakan disesuaikan dengan jenis data yang diperlukan yaitu:

Tabel 1. Jenis, Instrumen, Sumber data, Metode dan Waktu Penelitian

\begin{tabular}{clllll}
\hline No & Jenis Data & $\begin{array}{l}\text { Instrumen } \\
\text { Penelitian }\end{array}$ & $\begin{array}{l}\text { Sumber } \\
\text { Data }\end{array}$ & $\begin{array}{l}\text { Metode yang } \\
\text { digunakan }\end{array}$ & $\begin{array}{l}\text { Waktu } \\
\text { Pelaksanaan }\end{array}$ \\
\hline \multirow{2}{*}{1} & $\begin{array}{l}\text { Aktivitas } \\
\text { belajar } \\
\text { siswa }\end{array}$ & $\begin{array}{l}\text { Lembar } \\
\text { Observasi }\end{array}$ & Siswa & Observasi & Setiap pertemuan \\
\hline \multirow{2}{*}{2} & $\begin{array}{l}\text { Hasil belajar } \\
\text { siswa }\end{array}$ & Tugas & Siswa & Tes & Di akhir pertemuan II \\
\cline { 3 - 6 } & Tes hasil & Siswa & Tes & $\begin{array}{l}\text { Pertemuan III disetiap } \\
\text { akhir siklus }\end{array}$ \\
\hline
\end{tabular}

Data aktivitas siswa dianalisis secara diskriptif kualitatif berdasarkan hasil observasi dan refleksi. Sedangkan Data hasil observasi menggunakan kriteria aktivitas belajar sebagai berikut:

Tabel 2. Kriteria Aktivitas Belajar siswa

\begin{tabular}{lll}
\hline No & Skor & Kualifikasi \\
\hline 1 & $\mathrm{X} \geq 2,495$ & Sangat Aktif \\
\hline 2 & $2,165<\mathrm{X} \leq 2,495$ & Aktif \\
\hline 3 & $1,835<\mathrm{X} \leq 2,165$ & Cukup Aktif \\
\hline 4 & $1,505<\mathrm{X} \leq 1,835$ & Kurang Aktif \\
\hline 5 & $\mathrm{X}<1,505$ & Sangat Kurang Aktif \\
\hline
\end{tabular}

Untuk data hasil belajar siswa dianalisis secara diskriptif yaitu dengan menentukan skor rata-rata hasil tes (M) yang selanjutnya dikonversikan kedalam skala 100. Skor rata-rata hasil belajar dianalisis secara deskriptif berdasarkan proporsi siswa yang mengalami peningkatan ratarata. peningkatan rata-rata kelas dan ketuntasan belajar. Ketuntasan belajar dihitung berdasarkan KKM untuk mata pelajaran fisika yang ditetapkan adalah 65 (siswa dinyatakan tuntas belajar jika memperoleh nilai $\geq 65$ ) dan Kelas dinyatakan tuntas belajar apabila $85 \%$ telah memperoleh nilai 65. Berikut cara penghitungan rata-rata dan ketuntasan kelas yaitu : 
a. untuk rata-rata :

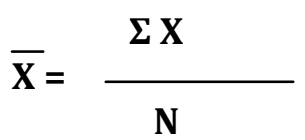

Keterangan :

$\overline{\mathrm{X}}=$ skor rata-rata

$\Sigma \mathrm{X}=$ jumlah keseluruhan skor siswa

$\mathrm{N}$ = jumlah siswa

( Sudjana, 1992 )

b. untuk ketuntasan klasikal :

KK : $\frac{\text { jumlah siswa yang memperoleh nilai } \geq 65}{\text { jumlah siswa yang ikut tes }} \times 100 \%$

Keterangan :

$\mathrm{KK}=$ Ketuntasan Klasikal.

\section{HASIL DAN PEMBAHASAN}

\section{A. Hasil Penelitian}

\section{Deskripsi Hasil Siklus 1}

Untuk menyiapkan pelaksanaan tindakan pada siklus I maka dilakukan langkah-langkah atau persiapan yang terdiri dari atas :

a. Menetapkan topik

b. Menyiapkan administrasi guru yang terdiri dari : silabus, program tahunan, program semester, agenda dan jurnal, buku nilai , analisis ulangan dan rencana pelaksanaan pembelajaran (RPP) yang disusun untuk 3 kali pertemuan yang materi pembelajaran meliputi: Pengaruh kalor terhadap zat, Perubahan wujud zat, Pemuaian panjang, luas dan volume, Konveksi, konduksi dan radiasi.

c. Menyusun tes hasil belajar dan instrumen penilaian yang berupa observasi.

d. Menyiapkan rancangan pembelajaran yang menyangkut strategi pembelajaran kooperatif tipe Think Pair Share.

Pada tahap pelaksanaan tindakan peneliti melakukan langkah-langkah sebagai berikut:

a. Kegiatan pendahuluan yaitu menggali kemampuan awal siswa dengan pertanyaan seperti pada rencana pelaksanaan pembelajaran sebagai apersepsi atau motivasi awal.

b. Pada kegiatan inti pada tiap pertemuan diawali dengan menyampaikan materi, tujuan pembelajaran dilanjutkan dengan membentuk kelompok yang terdiri dari 2 orang yaitu siswa kategori mampu dan siswa kategori kurang mampu berdasarkan analisis hasil ulangan sebelum penelitian seperti pada lampiran 2. Dimana kelompok 1 terdiri dari $1 \mathrm{~A}$ dan $1 \mathrm{~B}$, kelompok 2 terdiri dari $2 \mathrm{~A}$ dan $2 \mathrm{~B}$ dst. artinya A tergolong siswa yang mampu dan B tergolong siswa kurang mampu sehingga terbentuk 15 kelompok. Setelah terbentuk kelompok siswa diberikan permasalahan dalam bentuk pertanyaan yaitu : a) pertemuan I; Jelaskan perubahan wujud yang terjadi pada es jika dipanaskan !, b) pertemuan II; Dengan tujuan apakah kaca dengan bingkainya dibuat agak longgar? dan pertemuan III ; jelaskan perbedaan konveksi, konduksi dan radiasi !. Selama proses diskusi kelompok dilakukan pengamatan pada aktivitas siswa yang penilaiannya diberikan pada kelompok tersebut. Selama 5 - 10 menit kegiatan dilanjutkan dengan penyampaian hasil diskusi secara bergiliran. Untuk pertemuan I dilakukan sebanyak 4 kelompok, pertemuan II sebanyak 7 dan pertemuan sebanyak III 4 kelompok hingga 
semua kelompok dapat menyampaikan gagasan atau ide. Dari hasil diskusi, guru menambahkan materi yang belum diungkap siswa

c. Pada akhir kegiatan setiap pertemuan dibuat bersama dengan siswa tentang kesimpulan dilanjutkan dengan pemberian tugas pada pertemuan II dan melaksanakan tes pada pertemuan III.

Selama proses tindakan berlangsung dilakukan pengamatan pada lembar observasi dan memeriksa hasil ulangan yang dianalisis dalam daftar analisis hasil belajar seperti pada lampiran 4 dan analisis tersebut dimasukkan ke daftar nilai hasil belajar seperti pada lampiran 5 hingga diperoleh data sebagai berikut:

a. Aktivitas siswa. Hasil analisis data aktivitas siswa kelas XI IPA 3 SMA Negeri 1 Woja yang mengikuti pembelajaran fisika menggunakan model kooperatif Tipe Think Pair Share untuk Kompetensi dasar 7.4 Menguasai pengaruh kalor terhadap zat, dapat dijelaskan sebagai berikut. Skor rata-rata aktivitas siswa yang diperoleh pada siklus I adalah 1,80 berada pada kategori kurang aktif.

b. Hasil belajar siswa. Hasil analisis hasil belajar fisika siswa kelas XI IPA 3 SMA Negeri 1 Woja yang mengikuti pembelajaran fisika menggunakan model Kooperatif Tipe Think Pair Share disajikan sebagai berikut.

Tabel 3. Hasil Analisis Data Hasil Belajar Siswa Pada Siklus I

\begin{tabular}{lll}
\hline Kelas & Indikator & Skor \\
\hline \multirow{2}{*}{ XI IPA 3 } & Rata-rata & $\mathbf{6 6 , 9 3}$ \\
\cline { 2 - 3 } & Ketuntasan Klasikal & $\mathbf{7 7 \%}$ \\
\hline
\end{tabular}

Berdasarkan data diatas maka dapat disimpulkan bahwa hasil belajar siswa XI IPA 3 SMA Negeri 1 Woja sebagai berikut. rata-rata hasil belajar yang dicapai besarnya 66,93 dengan ketuntasan klasikal $\mathbf{7 7} \%$ ini menunjukkan adanya peningkatan hasil belajar yang sebelumnya 62,00. Namun hasil tersebut belum mencapai ketuntasan minimal yang diharapkan.

Berdasarkan hasil observasi dan hasil belajar siswa selama pelaksanaan pembelajaran pada siklus I, didapat bahwa pada awal pelaksanaan model pembelajaran Kooperatif Tipe Think Pair Share ditemukan beberapa hambatan diantaranya a). ada kelompok yang belum maksimal dalam kerjasam kelompok untuk meemecahkan masalah yang diberikanakbat dari pembagian kelompok yang kurang merata tingkat kemampuan sehingga dalam melaksanakan aktivitas kelompok ada yang diam dan ada yang aktif, b). belum terbiasanya siswa menyampaikan ide akibat dari adanya rasa malu dalam mengemukakan pendapat sehingga apa yang dipikirkan dengan apa yang sampaikan tidak sesuai dan c).Pengelolaan kelas yang kurang optimal karena belum terbiasa . Hambatan-hambatan tersebut dijadikan bahan pertimbangan dalam menyusun kegiatan pembelajaran pada siklus kedua

\section{Deskripsi Hasil Siklus II}

Untuk perencanaan sama dengan kegiatan pada siklus I hanya memperbaiki dalam pembentukan kelompok berdasarkan dari hasil belajar siklus I dan dalam pelaksaan tindakan berbeda pada permasalahan yang diberikan pada siswa. Dari hasil observasi, hasil belajar dan refleksi pada siklus I maka untuk kegiatan pembelajaran pada siklus kedua dengan mengisi lembar observasi untuk aktivitas siswa dan lembar daftar hasil belajar siswa, diperoleh data sebagai berikut:

a. Aktivitas siswa. Hasil analisis data aktivitas siswa kelas XI IPA 3 SMA Negeri 1 Woja yang mengikuti pembelajaran fisika menggunakan model kooperatif Tipe Think Pair Share , dapat dijelaskan sebagai berikut. Skor rata-rata aktivitas siswa yang diperoleh pada siklus I adalah 2,01 berada pada kategori cukup aktif. 
b. Hasil belajar siswa. Hasil analisis hasil belajar fisika siswa kelas XI IPA 3 SMA Negeri 1 Woja yang mengikuti pembelajaran fisika menggunakan model Kooperatif Tipe Think Pair Share dapat disajikan sebagai berikut

Tabel 3. Hasil Analisis Data Hasil Belajar Siswa Pada Siklus II

\begin{tabular}{lll}
\hline Kelas & Indikator & Skor \\
\hline \multirow{2}{*}{ XI IPA 3} & Rata-rata & $\mathbf{7 3 , 2 5}$ \\
\cline { 2 - 3 } & Ketuntasan Klasikal & $\mathbf{8 7} \%$ \\
\hline
\end{tabular}

Berdasarkan data pada table 4.2 diatas maka dapat disimpulkan bahwa hasil belajar siswa XI IPA 3 SMA Negeri 1 Woja sebagai berikut. Rata-rata hasil belajar yang dicapai besarnya 73,25 dengan ketuntasan klasikal $\mathbf{8 7 \%}$ ini menunjukkan adanya peningkatan hasil belajar yang sebelumnya $\mathbf{6 6 , 9 3}$. Hasil tersebut tergolong sudah mencapai ketuntasan minimal yang diharapkan, Berdasarkan hasil observasi dan hasil belajar selama pelaksanaan pembelajaran pada siklus II menunjukkan adanya peningkatan aktivitas dan hasil belajar siswa dengan memperkecil hambatan atau kendala yang dihadapi pada siklus I antara lain komunikasi yang tumbuh pada setiap kelompok karena anggota kelompok ada pemerataan kemampuan siswa sehingga aktivitas pembelajaran lebih kelihatan.

\section{B. Pembahasan}

Dari tahapan siklus yang dilaksanakan terkait dengan penerapan pembelajaran kooperatif tipe Think Pair Share (TPS) pada siklus I ada peningkatan peran aktif dalam kegiatan pembelajaran. Skor rata-rata aktivitas siswa yang diperoleh pada siklus I berada pada kategori kurang aktif dengan skor rata-rata 1,80 menjadi cukup aktif pada siklus II dengan skor 2,01. Hal ini menunjukkan bahwa ada perbaikan proses walaupun masih kurang. Semua itu disebabkan antara lain: siswa selalu diberitahu agar siswa selalu bekerja dalam kelompoknya, melakukan interaksi dengan teman, interaksi yang terjadi antara siswa dengan guru, siswa yang bertanya dan kegiatan dalam memecahkan masalah. Untuk hasil belajar siswa berdasarkan analisis ulangan di dapat adanya peningkatan dari belum tuntas dengan perolehan $77 \%$ pada siklus I menjadi tuntas pada siklus II dengan perolehan $87 \%$. Berdasarkan hasil yang diperoleh secara umum penelitian ini dapat menjawab permasalahan dan tujuan yang diharapkan yaitu : 1). dapat meningkatkan aktivitas belajar siswa dan 2) dapat meningaktkan dari hasil belajar. Tidak hanya itu siswa menemukan pengetahuan yang dibangun sendiri dan peranan guru sebagai fasilitator dapat ditingkatkan.

\section{SIMPULAN DAN SARAN}

\section{A. Simpulan}

Berdasarkan rumusan masalah, tujuan, dan hasil penelitian seperti yang telah diuraikan di atas maka dapat ditarik kesimpulan sebagai berikut.

a. Penerapan model pembelajaran Kooperatif Tipe Think Pair Share dalam pembelajaran fisika di kelas XI IPA 3 SMA Negeri 1 Woja ternyata dapat meningkatkan aktivitas siswa dari kategori kurang menjadi cukup aktif.

b. Penerapan model pembelajaran Kooperatif Tipe Think Pair Share dalam pembelajaran fisika di kelas XI IPA 3 SMA Negeri 1 Woja dapat meningkatkan hasil belajar dari belum tuntas menjadi tuntas

\section{B. Saran}

Berdasarkan temuan-temuan dan pembahasan hasil penelitian ini dapat dikemukakan saran-saran berikut.

a. Dengan model pembelajaran ini dapat memberikan model yang mudah, efektif dalam pengelolaan pembelajaran dikelas.

b. Untuk memperoleh kualitas pembelajaran yang lebih baik maka pihak pengelola di sekolah mengubah seting kelas yang konvensional menjadi kelas yang dinamis, mudah diatur sesuai dengan pola pembelajaran yang diinginkan. 


\section{DAFTAR RUJUKAN}

Arikunto Suharsimi. 2002. Prosedur Penelitian Suatu Pendekatan Praktek. Jakarta: Bumi Aksara.

Arikunto Suharsimi. 2008. Penelitian Tindakan Kelas. Jakarta: PT. Bumi Aksara.

Fathirma'ruf, F., \& M. Said, B. (2020). Pengembangan Perangkat Pembelajaran Konstruktivistik Model Teaching with Analogies (TWA) pada Mata Kuliah Database Management System (DBMS) untuk Meningkatkan Kemampuan Berpikir Kreatif Mahasiwa. Jurnal Teknologi Informasi dan Ilmu Komputer, 7(5), 1051-1060. doi:http://dx.doi.org/10.25126/jtiik.2020752388

Lie, A. 2002. Cooperative Learning, Gramedia Wdyasarana Indonesia ,Jakarta

Nur, M dan Wikandari. 2000. Pengajaran Berpusat pada Siswa dan Pendekatan Konstruktivis dalam Pengajaran. Surabaya: PSMS.

Panitia Penerimaan Siswa Baru. 2008. Data Penerimaan Siswa Baru SMA Negeri 1 Kempo. (Tidak Dipublikasikan).

Samani, M. 2006. Menjadi Guru Profesional dalam Persepektif UU Guru dan Dosen. Makalah. Disampaikan pada workshop Guru Berprestasi Nasional. Bandung, 29 Mei 2006.

Sudjana, Nana. 2004. Penilaian Hasil Proses Belajar Mengajar. Bandung.Remaja Rosdakarya.

Suharsimi Arikunto,2008. Dasar-dasar Evaluasi Pendidikan (Edisi Revisi), cetakan kedelapan,Penerbit Bumi Aksara.

Suyitno, Amin. 2006. Pemilihan Model-Model Pembelajaran dan Penerapannya di Sekolah. Semarang : Universitas Negeri Semarang 